\title{
NOTEWORTHY COLLECTION
}

\section{CALIFORNIA}

LOPHOCEREUS SCHOTTII (Engelm.) Britton \& Rose (CACTACEAE).-Riverside Co., Chuckwalla Mountains, Pilot Mountain 7.5' USGS quad, $33.62^{\circ} \mathrm{N}$, $115.32^{\circ} \mathrm{W}$ (WGS84), $482 \mathrm{~m}$ (1581 ft) elevation, approximately $1 \mathrm{~km}$ E of Corn Springs Campground, $14 \mathrm{~km}$ SE of Desert Center, 26 Oct 2013, M. A. Baker 17802 with M. Cloud-Hughes, A. Karl, and T. Thomas (ASU 289420!); 28 Sep 2013, J. Anderson 2013-05 with D. Bell and K. Clark (ASU 289052 [n.v]); 28 Sep 2013, D. Bell 6031 with J. Anderson and K. Clark (RSA 809190 [n.v.]). Two individuals: one approximately $3 \mathrm{~m}$ tall $\times 2 \mathrm{~m}$ wide growing in Olneya tesota A. Gray in an east-facing drainage in rocky, gravelly, sandy granitic alluvium; second approximately $1.5 \mathrm{~m}$ tall $\times 1.5 \mathrm{~m}$ wide growing at the base of a dead Fouquieria splendens Engelm. at the west-facing base of a granitic outcropping in rocky, gravelly, sandy granitic alluvium with Allionia incarnata L., Ambrosia dumosa (A. Gray) W.W. Payne, A. salsola (Torr. \& A. Gray) Strother \& B.G. Baldwin, Chamaesyce polycarpa (Benth.) Millsp., Cylindropuntia ramosissima (Engelm.) F.M. Knuth, Dasyochloa pulchella (Kunth) Willd. ex Rydb., Encelia farinosa A. Gray ex Torr., Fagonia laevis Standl., Fouquieria splendens, Ferocactus cylindraceus (Engelm.) Orcutt, Krameria bicolor $\mathrm{S}$. Watson, and Olneya tesota.

Previous knowledge. This species was originally collected by Schott in Sonora, Mexico in 1855 (MO 2015496!) and published under the basionym Cereus schottii Engelm. (Engelmann 1856).

The taxonomy of the species has changed several times and remains a matter of debate (Terrazas and Loza-Cornejo 2002, Arias et al. 2003). It was changed to Lophocereus schottii (Engelm.) Britton \& Rose by Britton and Rose in 1909 (Britton and Rose 1909). In 1984 the International Organization for Succulent Plant Study formed the International Cactaceae Systematics Group in an attempt to come to a consensus on taxonomy within the Cactaceae (Anderson 2001). The group lumped Lophocereus (A. Berger) Britton \& Rose and several other genera under the genus Pachycereus (A. Berger) Britton \& Rose, thereby changing the species name to Pachycereus schottii (Engelm.) D.R. Hunt (Hunt 1987). However, more recent work combining genetics and morphology suggests that Pachycereus is a paraphyletic genus and that several genera, including Lophocereus, should be resurrected (Arias et al. 2003, Arias and Terrazas 2009).

Lophocereus schotit is a basally-branched columnar cactus mainly found in Baja California, Sinaloa, and Sonora, Mexico. Until this discovery, the northernmost occurrences were in southern Arizona in Organ Pipe National Monument.

These two Corn Springs individuals were found in March 2013 by Buford Crites and Cameron Barrows. The discovery was reported by Kate Barrows, president of the Riverside-San Bernardino chapter of the California Native Plant Society (pers. comm., March 2013). Surveys of the area by several groups of botanists have not discovered any other individuals.
Significance. This is the first record for Lophocereus schottii in California. The closest record for the species is in Cañón de los Torrentes, Baja California, $40 \mathrm{~km}$ south of the international border. This record therefore represents a northern range extension of over $140 \mathrm{~km}$. This is also the first record for any Lophocereus species for California.

This discovery has occasioned much lively discussion regarding the possible origin of these disjunct plants. The first possibility is that they represent the last of a relict population. This hypothesis is supported by Stebbins and Major (1965), which identified the northern and eastern edges of the Colorado Desert as having a high number of relict species.

A second possibility is that the species was brought to the Corn Springs area by Native Americans. For thousands of years, Corn Springs served as a temporary home for several tribes of nomadic indigenous peoples (Bureau of Land Management 2014). The native peoples of southern Arizona and northern Baja, where the species is more common, ate the fruit and used the pulp for various medicinal purposes (Rebman and Roberts 2012). It is therefore possible that Lophocereus schottii made it to Corn Springs through trading amongst tribes.

The third possibility is that miners, who occupied the Corn Springs area from the early 19 th century through the early 1980's, planted Lophocereus schottii as an ornamental. There is a homestead area approximately $5 \mathrm{~km}$ west of Corn Springs Campground at Aztec Well where there are large, mature, presumably-planted saguaros. A thorough survey of the Aztec Well area has not been possible, due to the hazardous nature of exploring remote desert dwellings. The one homeowner we spoke with at Aztec Well, who was aware of the Lophocereus schottii individuals near the campground, assured the authors that there were no others at Aztec Well and that he had not seen any others in his many years of exploring the area. He also said that he knew of a botanist who was already aware of the individuals but did not reveal a name. His attitude toward unexpected visitors discouraged us from further inquiries.

The largest immediate threat to this disjunct population is collection for horticulture. Both plants are very close to a road, and both plants have had stems removed in the past.

Both Lophocereus schottii individuals appear to be in good health. Although it is difficult to estimate the age of cacti, data from long-term growth measurements of Lophocereus schottii at Organ Pipe National Monument (Parker 1988) indicate that the large, mature individual is likely less than 50 years old, while the small, immature individual is probably less than 40 years old. The past poaching of stems on each individual makes accurate age estimates even more difficult.

The mature plant flowered in late March 2013 and again in response to heavy summer rains in August/ September 2013. No fruit resulted from either of these flowering periods. Lophocereus schottii is not only an obligate outcrosser, but also it is largely pollinated by a particular moth, Upiga virescens (senita moth), which is closely associated with the cactus at every stage of its life cycle (Fleming and Holland 1998). In Fleming and Holland's 1998 study, pollination by Upiga virescens 
accounted for approximately $75 \%$ of fruit set in Lophocereus schottii.

A single flowering individual of an obligately outcrossing species cannot support a pollinator that relies on fruit development for its own reproduction. Halictid bees, which do occur at Corn Springs (USDA-ARS 2014), are also able to pollinate Lophocereus schottii, though much less successfully than the senita moth (Fleming and Holland 1998). But until the smaller Lophocereus schottii individual reaches sexual maturity, this relict population will remain static. Even if these two plants do eventually cross, their genetic diversity will remain very low.

Unfortunately, unless there are several more Lophocereus schottii individuals hidden in the hills nearby, in the absence of a substantial propagation effort, this relict occurrence is bound for extinction.

-Michelle A. Cloud-Hughes ${ }^{1}$, Desert Solitaire Botany and Ecological Restoration, San Diego, CA 92103. 'mcloudhughes@gmail.com; and MARC A. BAKER $^{2}$, Southwest Botanical Research, Chino Valley, AZ 86323.²mbaker6@asu.edu

\section{ACKNOWLEDGMENTS}

The authors would like to thank Andrew Sanders (UC Riverside Herbarium), Kate Barrows and Greg Suba (California Native Plant Society), Duncan Bell, Nick Jensen, and Michael Honer (Rancho Santa Ana Botanical Garden), Jim André and Tasha La Doux (Sweeney Granite Mountains Research Center), Tom Chester, Tim Thomas, and Neal Kramer for much thought-provoking discussion and debate on these enigmatic plants.

\section{Literature Cited}

Anderson, E. F. 2001. The Cactus Family. Timber Press, Portland, Oregon.

ARIAS, S. AND T. TerRaZAS. 2009. Taxonomic revision of Pachycereus (Cactaceae). Systematic Botany 34:68-83.

And K. CAmeron. 2003. Phylogenetic analysis of Pachycereus (Cactaceae, Pachycereeae) based on chloroplast and nuclear DNA sequences. Systematic Botany 28:547-557.
Britton, N. L. AND J. N. Rose. 1909. The genus Cereus and its allies in North America. Contributions from the United States National Herbarium 12:413-438.

EnglemanN, G. 1856. Synopsis of the Cactaceae of the Territory of the United States and adjacent regions. Proceedings of the American Academy of Arts and Sciences 3:259-314.

Fleming, T. H. AND J. N. Holland. 1998. The evolution of obligate pollination mutualisms: senita cactus and senita moth. Oecologia 114:368-375.

HARTMANN, S., J. D. NASON, AND D. BHATTACHARYA. 2002. Phylogenetic origins of Lophocereus (Cactaceae) and the senita cactus-senita moth pollination mutualism. American Journal of Botany $89: 1085-1092$.

HunT, D. R. 1987. Bradleya: Yearbook of the British Cactus and Succulent Society 5:93.

PARKER, K. C. 1988. Growth rates of Stenocereus thurberi and Lophocereus schottii in southern Arizona. Botanical Gazette 149:335-346.

Rebman, J. P. AND N. C. Roberts. 2012. Baja California plant field guide. 3rd ed. San Diego Natural History Museum and Sunbelt Publications, San Diego, CA.

Stebbins, G. L., JR. AND J. MAJOR. 1965. Endemism and speciation in the California flora. Ecological Monographs 35:1-35.

Terrazas, T. AND S. LozA-Cornejo. 2002. Phylogenetic relationships of Pachycereeae: a cladistic analysis based on anatomical-morphological data. Pp. 66-86 in T. H. Fleming and A. Valiente-Banuet (eds.), Columnar cacti and their mutualists: evolution, ecology, and conservation. University of Arizona Press, Tucson, AZ.

United States Department of Agriculture, Agricultural Research Service. Bee Biology and Systematics Laboratory: Bee Biology and Systematics Laboratory. Accessed via http://www. gbif.org/occurrence/658752050 on 2014-07-06.

UNited StATES DEPARTMENT OF THE INTERIOR, Bureau OF LAND Management. 2013. Corn Springs Campground. www.blm.gov/ca/st/en/fo/ palmsprings/corn_springs_campground.html. Accessed April 2014. 


\section{$2 \mathrm{BHL}$ Biodiversity Heritage Library}

Cloud-Hughes, Michelle A and Baker, Marc A. 2014. "California." Madroño; a West American journal of botany 61, 414-415.

https://doi.org/10.3120/0024-9637-61.4.414.

View This Item Online: https://www.biodiversitylibrary.org/item/225972

DOI: https://doi.org/10.3120/0024-9637-61.4.414

Permalink: https://www.biodiversitylibrary.org/partpdf/237702

\section{Holding Institution}

Smithsonian Libraries

\section{Sponsored by}

Biodiversity Heritage Library

\section{Copyright \& Reuse}

Copyright Status: In Copyright. Digitized with the permission of the rights holder License: https://creativecommons.org/licenses/by-nc-sa/4.0/

Rights: https://www.biodiversitylibrary.org/permissions/

This document was created from content at the Biodiversity Heritage Library, the world's largest open access digital library for biodiversity literature and archives. Visit BHL at https://www.biodiversitylibrary.org. 